\author{
Silvija Hanžić Deda \\ University of Zagreb, Croatia
}

\title{
METACOMPREHENSION AWARENESS OF PRIMARY SCHOOL PLURILINGUALS
}

\begin{abstract}
Summary. This qualitative-quantitative study examines the level of metacomprehension awareness in international primary school students before, while, and after reading narrative texts. The first part of the study brings a short overview of theoretical background and previous research pertaining to metacognition and metacognitive strategies, reading comprehension, and plurilingualism in the context of formal education. The second part describes the participants, along with their diverse personal experiences regarding language and education. Two tests and a brief questionnaire were used for collecting the majority of information. A semi-structured interview was conducted to inquire about the participants' attitudes towards reading narrative texts and the languages to which they give preference while reading such texts. The findings reveal that, at the age of ten, plurilingual students demonstrate a certain amount of metacomprehension awareness while reading narrative texts in English. No major differences were found between two language-specific groups defined by the students' mother tongues, but certain differences occurred between boys and girls. Established reading language and language preferences for reading narrative texts seem to play an important role in effective reading comprehension, whereas age seems to be a more critical factor in the development of metacomprehension awareness of plurilingual 10-year-olds.
\end{abstract}

Keywords: international primary school; metacomprehension strategy index; narrative texts; plurilingual readers; reading comprehension.

\section{Introduction}

The act of reading is generally performed with clear purposes: to receive and comprehend a conveyed message. To accomplish that, an individual is required to understand written pieces of information. In other words, it is essential to develop a certain degree of reading comprehension prior to seeking written resources, which is typically done by implementing various strategies. Reading in one's mother tongue can be a challenging activity, but then again, receiving written information in another language can be even more demanding. Many students around the world build their knowledge and understanding in one or more languages other than their mother tongues, and therefore, it is of vital importance to examine their strategic behavior while reading. English as a language of education for many students attending international schools worldwide is an example of such reading. The following study was designed to 
capture the reading comprehension strategies of plurilingual fourth-graders together with the relations between these strategies and students' reading comprehension scores.

\section{Theoretical Background and Previous Research}

The existing body of research dealing with the awareness of strategic behavior in reading mostly includes mature readers (e.g., Schraw \& Sperling Dennison, 1994; Mokhtari \& Reichtar, 2002; Yüksel \& Yüksel, 2011), and few were conducted among primary school children (e.g., Baumann, Seifert-Kessel \& Jones, 1992). Such phenomenon might be attributed to the late twentiethcentury conclusions that younger children are less aware of their metacognitive strategies in reading than high school or college students (Brown, 1985; Paris \& Winograd, 1990). Primary school is the foundation of any individual's education, and thus it is necessary to examine the potentials of strategic behavior and its influence on the reading skills of young plurilinguals. Metacognition has a substantial role in reading comprehension, and up to a certain degree, so does the age of a reader, but gender differences appear to be ambiguous. Brief theoretical background and review of previous studies will be provided in the following paragraphs.

\section{Metacognition and Reading}

The concept of metacognition was introduced in 1979, and it was defined as "knowledge and cognition about cognitive phenomena" (Flavell, 1979, p. 906). Flavell's model of cognitive monitoring consists of metacognitive knowledge and metacognitive experiences. The knowledge variables are: self, task, and strategies, whereas the experiences represent the metacognitive knowledge of which one becomes aware, and thus it modifies one's metacognitive knowledge base.

Several years later, Flavell's model was extended in order to study the relationship between metacognitive skills and reading (Baker and Brown 1984; Brown, 1985). The theoretical foundation of these two researchers was that metacognition equals knowledge of cognition plus regulation of cognition. 
The main purpose of studying metacognition is to determine how much a student knows about the features of thinking when he or she is the one performing the act of thinking. More precisely, there are two aspects of metacognition: 1) it is "the ability to reflect on one's own cognitive processes, to be aware of one's own activities while reading, solving problems, etc.", and 2 ) it is the system of self-regulatory mechanisms like checking, planning, monitoring, testing, revising, and evaluating (Baker \& Brown, 1984, pp. 4-5). In a similar way, Cleary (2017, p. 445) describes metacognition as a degree to which "people are aware of their own cognitive processes and/or can exert conscious control over them", while metacognitive monitoring is described as "monitoring and awareness of one's own cognitive processes, or a lack thereof". Studies that explore metacomprehension often discuss both phenomena. Many studies have established connections between the use of metacomprehension strategies and successful reading comprehension (e.g., Temelman-Yogev, Katzir \& Prior, 2020). However, Meniado's (2016) findings generate no such relations, but only a positive correlation between motivation to read and reading strategies, based on a sample of Saudi EFL students. What is more pertinent to this study, the connection between reading and metacognitive knowledge among primary school children has been studied (e.g., Pazzaglia, De Beni, \& Caccio, 1999), and there appeared to be some existence of metacognitive behavior at that age, although a tangible expansion appeared in middle school and continued growing until the university level.

\section{Reading Comprehension and Plurilingualism}

In this study, plurilingualism is observed as the "ability to use languages for the purposes of communication and to take part in intercultural interaction, where a person, viewed as a social actor has proficiency, of varying degrees, in several languages and experience of several cultures" (Coste, Moore \& Zarate, 2009, p. 11). The motive to choose that particular definition lies in the fact that it adequately describes the participants of this study, given the fact they had different language and cultural experiences and, in addition to that, they built their knowledge in a language other than their mother tongues. As they were expected to change their living circumstances quite 
often, on account of their parents' work requirements, one of their goals was to successfully adjust to a new language or cultural setting. One aspect of plurilingual and pluricultural competence "promotes the emergence of linguistic awareness, and even of metacognitive strategies, which enable the social actor to become aware of and to control his own 'spontaneous' ways of handling tasks and, in particular, their linguistic dimension" (ibid., p. 12). The main characteristic of participants' educational environment was the so-called plurilingual approach to pedagogy that allows for the use of other languages and language-related skills "to support learners who are in the process of learning English at the same time as they are learning content curriculum at school" (Stille \& Cummins, 2013, p. 630).

There are notions that plurilingual readers may benefit in self-efficacy from receiving explicit training in strategic reading accompanied by encouragement to read outside class (see Lipp, 2017). In terms of language transfer, Temelman-Yogev, Katzir, and Prior (2020) report on shared comprehension monitoring that can occur across two languages provided that the proficiency level in both languages is adequate.

\section{Metacognitive Strategies, Literacy Skills, and Young Age}

Adolescence is recognized as a phase of strong metacognitive growth (Pintrich \& Zusho, 2002). More specifically, Kolić-Vehovec and Bajšanski (2006) found stable and significant correlations between reading comprehension and comprehension monitoring towards the end of middle school (14- and 15-yearolds), which might be due to a higher level of efficacy in comprehension monitoring. However, there are indications that younger children also possess the ability to monitor and control their mental processes while reading or writing (e.g., Cox, 1994; Rowe, 1994; Ruan, 2004). Children's cognitive development and reading proficiency improve rapidly during the early years of primary school, which corresponds to the ages 5 through 10 . Beginners in reading - usually first-grade students - invest most of their effort in decoding words, i.e. finding familiar phonemes and morphemes in words (Ehri, 2005). On the following level, readers recognize the key information in the text. By the age of 10 , readers typically develop various strategies that can be 
employed while reading and writing. For example, creating keywords (de Bruin et al., 2011), focusing on meaning, setting the criteria for better understanding (which includes the purpose of reading), and using suitable fix-up strategies such as using context to predict meaning, finding structural cues, or using a dictionary (Davey \& Porter, 1982).

It is reasonable to expect 10 -year-olds to possess more metacognitive perceptions than the readers at the beginner stage (Paris \& Flukes, 2005). According to Piaget's theory of cognitive development, fourth-grade students fall into the late concrete operational stage that begins at the age of 7 and transforms into the formal operational stage around 11. Therefore, 10-yearolds possess more flexible and abstract thinking, with logic dominating over perceptions. Knowledge is built using mental actions. The latter developmental stage corresponds to middle school, during which abstract thinking gradually takes over thus enabling children to start hypothesizing and generalizing (Miller, 2010).

Based upon children's cognitive development and school training, Luke (2000) argues that teaching metacognitive strategies is crucial for turning students into text users and text critics. In comparison to younger students, Schmitt (2003) found that fourth-graders exhibited much better strategic knowledge while reading, and were also more capable of articulating it. Her results showed that 10 -year-olds successfully applied previewing, as well as predicting and verifying to achieve a better comprehension of narrative texts. At the same time, drawing from background knowledge and self-questioning somewhat decreased in importance, but summarizing and applying fix-up strategies became more frequently applied. However, purpose setting appeared to be the least salient metacomprehension strategy at that age.

More recent studies covering primary school students in a similar environment to the participants of this study, in terms of language, include the study of Kolić-Vehovec and Bajšanski (2007) that reports on middle-school bilingual students' metacomprehension. Language proficiency was positively associated with reading comprehension and comprehension monitoring skills. Since comprehension monitoring was identified as a reliable predictor of reading comprehension, the authors recommend explicit training for reading comprehension enhancement. Similarly, Šamo and Mikulec (2018) explored 
the changes in metacomprehension developments of a plurilingual boy during his middle school years by comparing his fifth-grade to eighth-grade test scores. His family language was Albanian, and for both social and educational purposes he also acquired Croatian. Since the age of 6 , he had been included in EFL classes. The results revealed somewhat unpredicted metacomprehension development since his reading proficiency and the ability to choose appropriate strategies deteriorated with time.

In the past decade, there have been few but valuable studies of even younger cohorts. For example, Destan and Roebers (2015) worked with 6year-olds to explore metacognitive monitoring and control skills in relation to self-assessment of literacy skills. Their results show that self-reported performance overestimation leads to less accurate monitoring and control skills. They highlight a major educational implication - early self-reported overestimation of performance may result in less time allocated for learning or error correction, the result of which is insufficient learning. Zápotočná, Urban, and Urban (2020) studied reading comprehension and metacomprehension in Slovak preschool children from families with low and middle socioeconomic status (SES). Their findings demonstrate that preschool children were able to perform some level of metacognitive monitoring. In their case, higher SES was associated with better performance on all literacy skills, but the children from lower SES showed significantly lower self-confidence by underrating their accurate responses.

\section{Reading Comprehension, Metacognitive Monitoring, and Gender}

Although some differences in reading comprehension concerning gender have been examined and confirmed (e.g., Rutter et al. 2004; Lietz, 2006), some researchers claim there is a lack of relevant evidence that girls outperform boys on reading comprehension tests (e.g., White, 2007). Some research suggests that metacognitive monitoring might be perceived in different ways between male and female readers (e.g., Ackerman, Nocera, and Bargh, 2010), but most such findings tend to be inconclusive (e.g., Nietfeld, Shores \& Hoffman, 2014). Focusing on a specific age group, secondary analyses of reading comprehension skills (e.g., Klecker, 2006; Lynn \& Mikk, 2009) indicate that 
10-year old girls had higher reading comprehension scores than boys in all countries involved. In other words, boys appeared to have more difficulties in reading comprehension due to a number of reasons. Similar observations were made by Kolić-Vehovec and Bajšanski (2006), whose findings showed better performance of middle-school girls on reading comprehension tests, comprehension monitoring, as well as the use of strategies to achieve better comprehension while reading.

\section{Research Design}

\section{Objectives and Research Questions}

The main objective of this study is to inquire about the strategic behavior of plurilingual 10-year-olds who read narrative texts in English, and their awareness of such behavior. Associations between their awareness of strategic behavior while reading and their attitudes toward reading, language preferences, and their reading comprehension scores will be explored. Additional attention will be given to possible mother tongue and gender-related differences between subgroups. In line with that, the following research questions were formed:

1. Which metacomprehension strategies are most accessible to plurilingual 10-year-olds before, during, and after reading a narrative text?

2. What level of metacomprehension awareness is attainable to a group of plurilingual primary school students who read narrative texts in English?

3. What differences can be recognized when comparing subgroups formed according to participants' mother tongues and gender?

4. How does metacomprehension awareness relate to reading comprehension, participants' attitudes toward reading narrative texts, and their reading-language preferences? 


\section{Participants}

The participants in this case study were nineteen fourth-graders, ten boys and nine girls, attending an international school in Zagreb, with an average age of 10,1 at the time of testing. Their personal backgrounds significantly varied as most of them often changed their place of residence, and consequently, schools. The only constant in their education was the English language in which all school subjects were taught. Croatian was the language of environment for all participants during their residence in Croatia, and it was one of the core school subjects but it was taught separately to advanced learners and beginners. All participants chose to learn between one and three foreign languages offered as extra activities (French, German, and Italian). Russian, Chinese, and Polish participants attended school programs in their mother tongues, which were mostly organized on weekends. Such mother tongue classes intended for expats are frequently held with groups combining students of different ages and reading abilities. In comparison to Croatian taught as a mother tongue in school, such classes are less frequent and often more intense. Apart from that, some of the students from this group were homeschooled in their mother tongue, and they periodically took standardized tests to progress at the same rate as their peers residing in their country of origin. At the time this study was conducted, no reading difficulties were reported for this group, and all students had been receiving formal education in English for at least one year, which means they were fully capable of reading both non-narrative and narrative texts in that language, the latter ones being in the focus of this study. Their reading routines and habits in English had been continually developed through both curricular and extracurricular activities, and they had been constantly encouraged by their teachers to read for pleasure (e.g., peer-to-peer book recommendations, attending library evening events, etc.). Even though the routines were the same for all students, the contents of their yearly reading plans were differentiated according to their levels of English inclined to dynamic changes instigated by the simultaneous input of both the language and other educational contents belonging to primary education.

For subgroup comparison, the students were divided into two groups, 
depending on the status of the Croatian language in their language repertoires (Coste et al., 2009). An outline of their diverse language backgrounds will be shown by listing their languages in the order of acquisition, parental languages, and places of residence. The first group (Table 1), in further discussion referred to as 'Croatian' (C), consisted of eight students whose mother tongue was Croatian. Among them, five students were born in Croatia, into Croatian families, but they had been attending school in English since the very beginning. The remaining three students were born abroad, lived there, and attended preschool institutions in English. This group comprises two subgroups formed according to the place of residence and migration. Alongside Croatian and English lessons that were both equally represented in the core curriculum, all students from this group learned other foreign languages, so they spoke either three or four languages.

\section{Table 1}

Participants' language profiles - the Croatian group

\begin{tabular}{|c|c|c|c|c|}
\hline \multicolumn{5}{|c|}{ Croatia-based } \\
\hline Student & $\begin{array}{l}\text { Language } \\
\text { repertoire }\end{array}$ & $\begin{array}{l}\text { Mother's } \\
\text { language(s) }\end{array}$ & $\begin{array}{l}\text { Father's } \\
\text { language(s) }\end{array}$ & $\begin{array}{l}\text { Countries } \\
\text { of } \\
\text { residence }\end{array}$ \\
\hline $\mathbf{S 1 3}$ & $\begin{array}{l}\text { Croatian, } \\
\text { English, } \\
\text { French }\end{array}$ & \multirow{5}{*}{ Croatian } & \multirow{5}{*}{ Croatian } & \multirow{5}{*}{ Croatia } \\
\hline $\mathbf{S 1 7}$ & $\begin{array}{l}\text { Croatian, } \\
\text { English, } \\
\text { German }\end{array}$ & & & \\
\hline $\mathbf{S 1 0}$ & $\begin{array}{l}\text { Croatian, } \\
\text { English, } \\
\text { Italian, } \\
\text { German }\end{array}$ & & & \\
\hline s6 & $\begin{array}{l}\text { Croatian, } \\
\text { English, } \\
\text { French, } \\
\text { German }\end{array}$ & & & \\
\hline S16 & $\begin{array}{l}\text { Croatian, } \\
\text { English, } \\
\text { French, } \\
\text { German }\end{array}$ & & & \\
\hline $\mathbf{S 1 8}$ & $\begin{array}{l}\text { Croatian, } \\
\text { English, } \\
\text { French, } \\
\text { German }\end{array}$ & Croatian & $\begin{array}{l}\text { Croatian, } \\
\text { English, } \\
\text { Italian }\end{array}$ & USA, Croatia \\
\hline
\end{tabular}




\begin{tabular}{|c|c|c|c|c|}
\hline \multicolumn{5}{|c|}{ Croatian origin } \\
\hline $\mathbf{S 1 9}$ & $\begin{array}{l}\text { Croatian, } \\
\text { Italian, } \\
\text { English, } \\
\text { French }\end{array}$ & $\begin{array}{l}\text { Croatian, } \\
\text { Italian }\end{array}$ & $\begin{array}{l}\text { Croatian, } \\
\text { Italian }\end{array}$ & Italy, Croatia \\
\hline $\mathbf{S 1 5}$ & $\begin{array}{l}\text { Croatian, } \\
\text { English, } \\
\text { German }\end{array}$ & $\begin{array}{l}\text { Croatian, } \\
\text { English }\end{array}$ & Croatian & $\begin{array}{l}\text { Australia, } \\
\text { Croatia }\end{array}$ \\
\hline
\end{tabular}

The second group (Table 2), in further discussion referred to as 'International' (I), consisted of eleven students who had various mother tongues due to their origins. During the past decade, they had moved between two or three countries and schools. Apart from English and their mother tongues, all students from this group learned other foreign languages; some languages were their own choices, whereas the others were the languages of their living environment and, consequently, they would be either formally learned or acquired at some point. The students in this group spoke between four and six languages.

\section{Table 2}

Participants' language profiles - the International group

\begin{tabular}{|c|c|c|c|c|}
\hline \multicolumn{5}{|c|}{ Indo-European language mother tongue } \\
\hline Student & $\begin{array}{l}\text { Language } \\
\text { repertoire }\end{array}$ & $\begin{array}{l}\text { Mother's } \\
\text { language(s) }\end{array}$ & $\begin{array}{l}\text { Father's } \\
\text { language(s) }\end{array}$ & $\begin{array}{l}\text { Countries of } \\
\text { residence }\end{array}$ \\
\hline S5 & $\begin{array}{l}\text { Slovene, Spanish, } \\
\text { English, Croatian, } \\
\text { Italian, German }\end{array}$ & Slovene & $\begin{array}{l}\text { Croatian, } \\
\text { Slovene }\end{array}$ & $\begin{array}{l}\text { Slovenia, Spain, } \\
\text { Croatia }\end{array}$ \\
\hline S11 & $\begin{array}{l}\text { Slovene, English, } \\
\text { Croatian, Italian, } \\
\text { German }\end{array}$ & Slovene & Slovene & Slovenia, Croatia \\
\hline $\mathbf{S 1 2}$ & $\begin{array}{l}\text { Polish, Croatian, } \\
\text { English, German, } \\
\text { French }\end{array}$ & $\begin{array}{l}\text { Polish, } \\
\text { Croatian }\end{array}$ & Croatian & Poland, Croatia \\
\hline s9 & $\begin{array}{l}\text { Polish, English, } \\
\text { Croatian, German }\end{array}$ & $\begin{array}{l}\text { Polish, } \\
\text { English }\end{array}$ & Polish & Poland, Croatia \\
\hline S1 & $\begin{array}{l}\text { Polish, English, } \\
\text { Croatian, French, } \\
\text { German }\end{array}$ & $\begin{array}{l}\text { Polish, } \\
\text { Croatian }\end{array}$ & $\begin{array}{l}\text { Polish, } \\
\text { English, } \\
\text { Croatian }\end{array}$ & $\begin{array}{l}\text { Poland, Turkey, } \\
\text { Croatia }\end{array}$ \\
\hline S14 & $\begin{array}{l}\text { Slovak, English, } \\
\text { German, Croatian }\end{array}$ & Slovak & $\begin{array}{l}\text { Slovak, } \\
\text { English }\end{array}$ & Slovakia, Croatia \\
\hline S4 & $\begin{array}{l}\text { Russian, English, } \\
\text { Croatian, German, } \\
\text { French }\end{array}$ & $\begin{array}{l}\text { Russian, } \\
\text { Croatian }\end{array}$ & Russian & Russia, Croatia \\
\hline $\mathbf{S 2}$ & $\begin{array}{l}\text { English, French, } \\
\text { Croatian, German }\end{array}$ & $\begin{array}{l}\text { English, } \\
\text { French }\end{array}$ & $\begin{array}{l}\text { English, } \\
\text { Croatian }\end{array}$ & Canada, Croatia \\
\hline
\end{tabular}




\begin{tabular}{|c|c|c|c|c|}
\hline \multicolumn{5}{|c|}{ Indo-European language mother tongue } \\
\hline s7 & $\begin{array}{l}\text { Spanish, English, } \\
\text { Croatian, French, } \\
\text { German }\end{array}$ & Spanish & $\begin{array}{l}\text { Spanish, } \\
\text { English }\end{array}$ & Chile, Croatia \\
\hline \multicolumn{5}{|c|}{ Turkic language mother tongue } \\
\hline s8 & $\begin{array}{l}\text { Kazakh, Russian, } \\
\text { English, German, } \\
\text { French }\end{array}$ & $\begin{array}{l}\text { Kazakh, } \\
\text { Russian }\end{array}$ & $\begin{array}{l}\text { Kazakh, } \\
\text { Russian }\end{array}$ & $\begin{array}{l}\text { Kazakhstan, } \\
\text { Croatia }\end{array}$ \\
\hline \multicolumn{5}{|c|}{ Sino-Tibetan language mother tongue } \\
\hline S3 & $\begin{array}{l}\text { Chinese, Croatian, } \\
\text { English, German }\end{array}$ & $\begin{array}{l}\text { Chinese, } \\
\text { Croatian }\end{array}$ & Chinese & China, Croatia \\
\hline
\end{tabular}

\section{Instruments}

Four instruments were used in this study: the My Language Biography questionnaire (Lujić \& Hanžić Deda, 2018), the Metacomprehension Strategy Index (Schmitt, 1990), a reading comprehension test intended for grade 4, and a semi-structured interview. All testing was conducted in English.

Firstly, it was necessary to collect students' personal information relevant to this study: the number of languages they spoke, and the number of times they changed places of residence. The My Language Biography (MLB) questionnaire was designed according to the British version of the language portfolio for primary school students. It had been piloted with a group of students with similar personal characteristics to the group of subjects in this study. Secondly, the Metacomprehension Strategy Index (MSI) designed by Maribeth Cassidy Schmitt was applied to measure international primary school students' awareness of strategic reading. It was proven both valid and reliable on several occasions (Schmitt, 1990). The questionnaire consists of 25 multiple-choice items, each offering four options. Items 1 to 10 have statements regarding the activities which a student could apply before reading. Next, items 11 to 20 offer the activities which could be used during reading. Finally, items 21 to 25 present the activities that could be chosen after reading a story.

The metacognitive strategies measured by the MSI are divided into six categories: predicting and verifying, previewing, purpose setting, selfquestioning, drawing from background knowledge, and finally, summarizing and applying fix-up strategies (Table 3). These categories are distributed 
through the questionnaire in the form of four-option choice items. Consequently, one of the four choices in each question indicates metacomprehension strategy awareness. On the one hand, this instrument identifies the strategic preferences of individual students, and on the other, it indicates whether students are aware of their own strategic behavior before, while, and after reading a narrative text.

\section{Table 3}

Strategies measured by the MSI

\begin{tabular}{lll}
\hline Strategy categories & $\begin{array}{l}\text { Abbreviations in } \\
\text { later displays }\end{array}$ & Items \\
\hline Predicting and Verifying & P \& V & $1,4,13,15,16,18,23$ \\
\hline Previewing & PV & 2,3 \\
\hline Purpose setting & PS & $5,7,21$ \\
\hline Self-questioning & SQ & $6,14,17$ \\
\hline $\begin{array}{l}\text { Drawing from background } \\
\text { knowledge }\end{array}$ & DBK & $8,9,10,19,24,25$ \\
\hline $\begin{array}{l}\text { Summarizing and applying } \\
\text { fix-up strategies }\end{array}$ & S \& A fix-up & $11,12,20,22$ \\
\hline
\end{tabular}

To capture participants' reading comprehension levels in English, a typical test for grade 4 was used - a type of test all participants were familiar with so that procedural errors could be ruled out in interpretation. The test comprised a narrative text (that had never been seen by any of the participants prior to that moment) containing 256 words, and five questions (two open-ended questions, a multiple-choice question, a gap-fill task, and a matching task), with a total of 20 points. For more insight into the students' interests in reading and their language preferences for reading narrative texts, they were interviewed by a neutral but familiar teacher. The interview questions inquired about students' attitudes towards reading narrative texts: (1) the level of enjoyment in reading, (2) reasons for reading, (3) favorite genres, and (4) preferred languages for reading narrative texts. 


\section{Procedure}

After obtaining the compulsory written permissions from the school administration and parents, the participants of this study were given the questionnaires: the MLB was completed individually, and the next day, the MSI was read aloud to the students, statement by statement, while they were making their choices to answer each question. They were asked to be honest with their choices, and also informed that they could ask for additional clarifications. In the following week, a reading comprehension test was administered. Finally, a semi-structured interview was conducted with each participant individually. The collected data was analyzed using predominantly descriptive statistics due to the relatively small number of participants. Most results are easily interpretable from the tables, and the applied statistical procedures were the variety intended for smaller groups of participants.

\section{Results and Discussion}

\section{Metacomprehension Strategy Awareness}

The results of the MSI will be approached from multiple perspectives. To answer the first research question, item frequency will be shown to indicate both the most and the least accessible metacomprehension strategies to this group of participants. As every question offers four options, only one indicates metacomprehension strategy awareness (Schmitt, 1990, p. 459), and therefore is accepted as a correct answer.

Table 4 shows how many participants out of the total 19 selected the correct statement in each item, along with its respective category. As Table 4 shows, with $f=15$ being the highest frequency, and $f=2$ being the lowest, the overall distribution can be divided into three groups: high accessibility (frequency between 11 and 15), medium accessibility (frequency between 7 and 9), and low accessibility (frequency between 2 and 5). In other words, the group of most accessible strategies comprises one strategy used before reading (to look at the title to see what the story is about), two strategies applied during reading (to find sense and to check one's ability to independently 
reiterate the main points of the story), and two strategies used after reading (to put oneself in the shoes of the character appearing in the story, and to reflect on one's existing knowledge recognized in the story).

\section{Table 4}

MSI item frequency

\begin{tabular}{|c|c|c|}
\hline Category & Statement & $\mathbf{f}$ \\
\hline PV & Read the title to see what the story is about. & 15 \\
\hline DBK & $\begin{array}{l}\text { Think about how I would have acted if I were the main } \\
\text { character in the story. }\end{array}$ & 13 \\
\hline S \& fix-up & $\begin{array}{l}\text { Check to see if the story is making sense by seeing if I can tell } \\
\text { what's happened so far. }\end{array}$ & 12 \\
\hline S \& fix-up & $\begin{array}{l}\text { Stop to retell the main points to see if I am understanding what } \\
\text { has happened so far. }\end{array}$ & 11 \\
\hline DBK & $\begin{array}{l}\text { Think about how the story was like things I already knew about } \\
\text { before I started reading. }\end{array}$ & 11 \\
\hline PV & Look at the pictures to see what the story is about. & 9 \\
\hline $\mathbf{P} \& \mathbf{V}$ & Make some guesses about what I think will happen in the story. & 8 \\
\hline DBK & $\begin{array}{l}\text { Keep thinking of what I already know about the things and } \\
\text { ideas in the story to help me decide what is going to happen. }\end{array}$ & 8 \\
\hline SQ & $\begin{array}{l}\text { Ask myself questions that I would like to have answered in the } \\
\text { story. }\end{array}$ & 7 \\
\hline DBK & $\begin{array}{l}\text { Think of what I already know about the things I see in the } \\
\text { pictures. }\end{array}$ & 7 \\
\hline SQ & $\begin{array}{l}\text { Check to see if I can answer any of the questions I asked } \\
\text { before I started reading. }\end{array}$ & 7 \\
\hline P \& V & Check to see if my guesses were right or wrong. & 7 \\
\hline P \& V & Make a lot of guesses about what is going to happen next. & 7 \\
\hline S \& fix-up & $\begin{array}{l}\text { Retell the main points of the whole story so that I can check to } \\
\text { see if I understood it. }\end{array}$ & 7 \\
\hline DBK & Think of what the people in the story might be like. & 5 \\
\hline SQ & Try to answer the questions I asked myself. & 5 \\
\hline PS & Check to see if I met my purpose for reading the story. & 5 \\
\hline
\end{tabular}




\begin{tabular}{|c|c|c|}
\hline Category & Statement & $\mathbf{f}$ \\
\hline PS & Decide on why I am going to read the story. & 5 \\
\hline S \& fix-up & $\begin{array}{l}\text { Reread some parts or read ahead to see if I can figure out what } \\
\text { is happening if things aren't making sense. }\end{array}$ & 4 \\
\hline$P \& \mathbf{V}$ & $\begin{array}{l}\text { Use the title and the pictures to help me make guesses about } \\
\text { what will happen in the story. }\end{array}$ & 4 \\
\hline P \& V & Try to see if my guesses are going to be right or wrong. & 3 \\
\hline P \& V & Think about what made me make good or bad predictions. & 3 \\
\hline DBK & Think about where the story might be taking place. & 2 \\
\hline P \& V & $\begin{array}{l}\text { Keep thinking about the title and the pictures to help me decide } \\
\text { what is going to happen next. }\end{array}$ & 2 \\
\hline PS & $\begin{array}{l}\text { Use my questions and guesses as a reason for reading the } \\
\text { story. }\end{array}$ & 2 \\
\hline
\end{tabular}

On the other hand, the least accessible strategies before reading were to guess the purpose for reading the story using one's own questions, to think about the setting of the story, to make predictions using the title and illustrations, to decide about the purpose of reading, and to think about the characteristics of the people appearing in the story. The least accessible strategies during reading include continuous thinking about how the title and images can help predict the storyline, the self-assessment of guesses taken about the story, additional reading of paragraphs in order to make more sense of the story, and trying to answer one's own questions about the story. The two least accessible strategies after reading were to reflect on one's own motives to make good or bad predictions, and to establish whether the reader's purpose of reading the story was met. All in all, five strategies belonging to three categories are in the group with a higher frequency indicating better accessibility, whereas the remaining strategies appear in the other two groups showing lower accessibility.

Points were scored in all six categories, wherein predicting and verifying, drawing from background knowledge, and summarizing and applying fix-up strategies were the most frequently reported as used by the participants. Previewing was used by sixteen, and self-questioning by fourteen students. 
Just over half of the students indicated awareness in purpose setting, which was the least frequent category of strategies. Namely, all three purpose-setting statements were placed in the lowest frequency group. In the absence of references coming from a plurilingual context, these results can be compared to the strategic behavior of English-speaking fourth-graders tested using the same instrument (Schmitt, 2003). In both studies, purpose setting was least accessible, whereas, prediction, previewing, and summarizing accompanied by fix-up strategies were the most accessible strategies. Selfquestioning, was in both instances, somewhere in the middle.

The overall scores on the MSI seem to be somewhat lower than half of the total 25 points. While testing 8 to 13 -year-olds in Spanish, Jiménez et al. (2009) also found that younger students had lower metacognition and executive functions in reading. In this study, S9 stands out with 19 points, which is by far the highest score, and S19 scored only 4 points, but that is quite close to the next higher scores (e.g., S3, S4, S6, all with five points). In other words, the average results indicate a relatively low metacomprehension awareness, where $M=9$ represents just above one-third of the total 25 points (see Fig. 1). However, on the spectrum of all scores, one student scored exceptionally high, but the lowest-scoring student was not exceptionally low in comparison to his first neighbors (S3, S4, and S6).

Figure 1 shows individual scores on the MSI that range between 4 and 19 points. The mean value $M=9$ was reached by two students ( $S 13$ and $S 17$ ), nine students exceeded it (S7, S8, S9, S10, S11, S14, S15, S16, and S18), and eight students scored below it (S1, S2, S3, S4, S5, S6, S12, and S19). Thirteen scores fall into the first standard deviation, which is 3,49 points above and below the mean line. However, five students fall into the second standard deviation, which is 6,98 points above and below the mean line, while one student falls into the third standard deviation. The mean score is sixteen points below the top score, which puts the overall result in the lower half of the 25point scale, except for two boys (S9 and S18). The mean value and the highest possible score are marked in dotted lines. The difference between them demonstrates that there is a significant amount of space to be filled in the following years as the participants continue to develop their metacomprehension awareness in middle school, as proposed by 
Mirandola et al. (2008). This finding answers the second research question. Similar outcomes also appear in earlier studies (e.g., Pazzaglia, De Beni \& Caccio, 1999).

\section{Figure 1}

Individual results with a marked difference between the mean value and the highest possible score

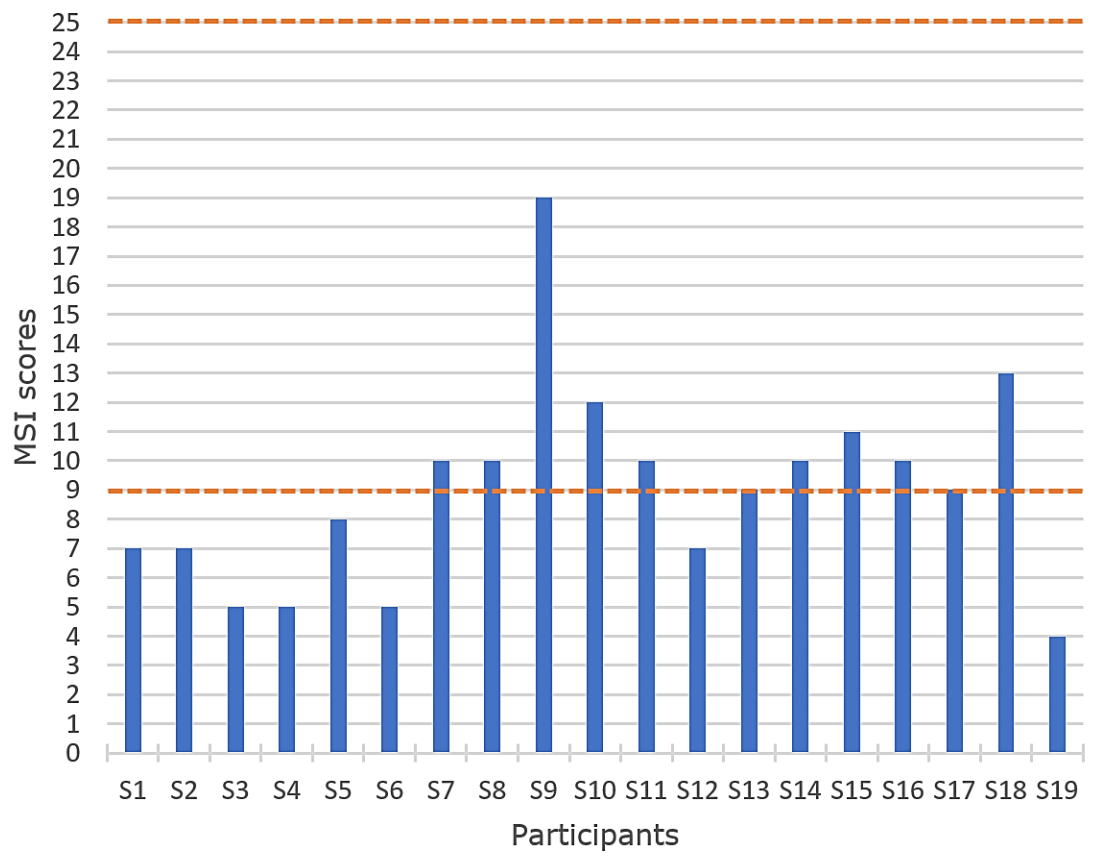

\section{Reading Comprehension}

The reading comprehension test was administered to the entire group of participants at the same time, but they completed it individually. The mean score of the group was $M=16,05$ points, with the standard deviation of $\mathrm{SD}=2,36$. Ten participants scored above the mean value, and nine scored below. S1 had the highest score, equal to the maximum number of points, whereas S19 had the lowest score. Other participants scored between those numbers, which shows no scores below 60 percent. Figure 2 illustrates 
the dispersal of scores on both tests.

\section{Figure 2}

Dispersal of scores - Metacomprehension Strategy Index (left) and reading comprehension test (right)
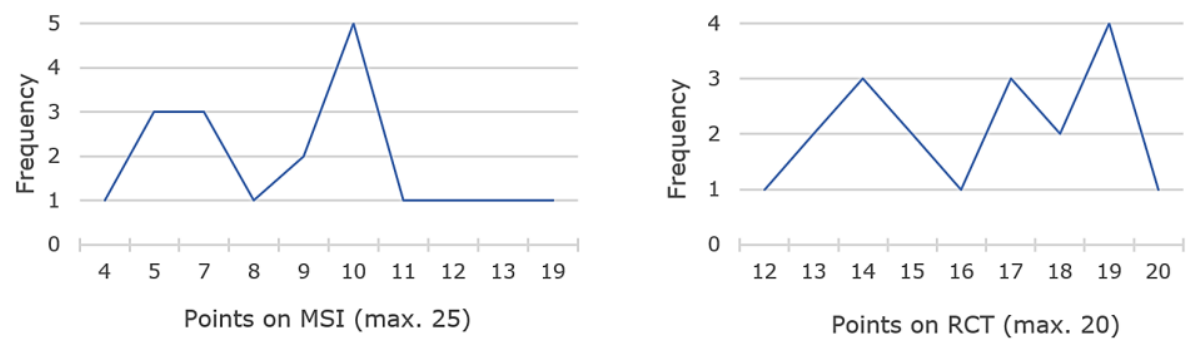

The small sample size is insufficient for generalization, and the linguistic diversity of participants likely contributed to the non-normal data distribution. Therefore, the Spearman rank-order correlation coefficient was used to determine the relationship between participants' awareness of metacomprehension strategies and their reading comprehension. The coefficient showed low positive correlation $\left(r_{s}=0,25\right)$ with no statistical significance (2-tail p-value $=, 30$, where $a=, 05$ ), which, in part, answers the fourth research question. Some of the earlier studies generated similar but stronger relations for Spanish-speaking students similar in age (e.g., Jiménez et al., 2009). In this particular case, the relation between strategic behavior and reading comprehension is perhaps best illustrated using a histogram view of both variables displayed for each participant (see Appendix). Based on previous findings involving bilingual participants (e.g., Kolić-Vehovec \& Bajšanski, 2007), it is anticipated that reading comprehension and metacomprehension awareness form a stronger and more significant correlation in the following years.

All participants but $\mathrm{S} 9$ had higher scores on the reading comprehension test than on the MSI, which indicates functioning reading comprehension skills accompanied by predominantly low awareness of strategic behavior. There are several groups of scores on both tests. Firstly, S9, who had high scores on both tests. Secondly, there is S10, with medium scores close on both tests. That 
corresponds to the notion that capable readers possess a better awareness and sense of suitability of their reading strategies (Martin, 1994). Next was a group of students with medium scores on both tests, but with a greater difference between the RCT and the MSI (S7, S8, S11, S13, S14, S15, S17, and S18). According to some studies, the ineffective use and regulation of strategies might be obstructing reading comprehension even more than the lack of strategic behavior while reading (e.g., Kletzien, 1992). The fourth group of students had high RCT scores, but very low MSI (S1, S2, S3, S4, S5, S6, S12, and S19), which may indicate the unawareness of strategic behavior underlying successful reading comprehension.

\section{Attitudes Toward Reading and Language Preferences}

The interview results reveal that fourteen students had a positive attitude toward reading narrative texts, and five of them reported to 'like it so-so'. None of the students expressed a negative attitude (Figure 3 ).

\section{Figure 3}

Participants' attitudes toward reading narrative texts

$$
\begin{aligned}
& \text { - Positive attitude } \\
& \text { - So-so attitude } \\
& \text { - Negative attitude }
\end{aligned}
$$

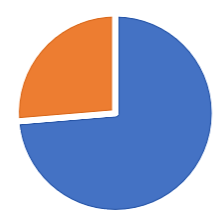

The most favored genres of reading materials were comedies, adventures, fantasies, fables, and graphic novels. Similarly, Norwegian 10- and 11-yearolds showed the highest preference for reading humorous books, superhero adventures, fairy tales, and science fiction within their extensive reading program in English. However, their book preferences seemed to be genderrelated (Birketveit, Rimmereide, Bader \& Fisher, 2018).

Self-reported motives for reading were: gaining new knowledge, relaxation, fun pastime, active use of imagination. Then again, the reasons to 
like reading 'so-so' were twofold: on the one hand, there was a positive connotation (e.g., reading is a relaxing activity; can be both entertaining and boring but useful), and on the other hand, there was a negative connotation: having something better to do, or enjoying reading specific genres (e.g., detective stories or adventures), but disliking all others. In comparison, 9 to 11-year-old bilinguals from Singapore listed their reasons for reading in English as follows: for enjoyment, for learning new things, for relaxation, for better grades, and to improve the language. On the other hand, reading in their mother tongues reflected different reasons as the most important: for better grades, and to improve the language, whereas the remaining three reasons followed (Sun et al., 2020).

In this study, the preferred language for reading was predominantly English, and it was selected by twelve students. Similar findings emerged from the previously mentioned study where reading in English was mainly considered more enjoyable than reading in students' mother tongues, Chinese or Malay (ibid). Four students from this study, S3, S4, S9, and S14, chose their mother tongues to be their favorite languages to read in, eleven students put English before their mother tongues. One participant (S19) put Italian first, which is understandable since that was the language of his immediate environment in his early childhood and was still partially spoken at home. English was positioned in the second place six times, by those students who selected their mother tongues as first, except for S11 who put his mother tongue in third place. Only S4 put English in third place, which was probably because she had started learning English only a year and a half earlier, and her mother tongue was more similar to Croatian than to English. All in all, the described outcomes indicated that more than two-thirds of the participants were comfortable with English as a language in which they read narrative texts.

Two students put Croatian in the first place (S10 and S11), ten students in the second place, and five put it in third place. Other languages listed were the ones the students had learned recently, mostly within the school context. Apart from being the mother tongue of eight students, Croatian appeared to be important to most of the students because it was part of the core curriculum, and the students were encouraged to read in it, almost equally as they were in English. Three students reported not having a third 
language to read in, and all three expressed reservations about reading stories or books in other languages they learned.

Five students (S5, S8, S11, S12, and S19) ranked their mother tongues third. They all conveyed the same motive for making such choices: first and second languages held more importance in the educational context, considering their current and future plans.

In an attempt to complete answering the fourth research question, a further analysis was conducted, and it showed no statistically significant correlations between participants' metacomprehension awareness and other two variables - attitudes toward reading narrative texts and their readinglanguage preferences.

\section{Differences In Metacomprehension Awareness Between Groups}

The Croatian and the International group were compared by the mean values scored in each of the six categories of the MSI. The lowest level of awareness appeared in the category of purpose setting, whereas the highest level was recorded in the category of drawing from background knowledge. These two, together with the category of self-questioning, showed no differences between the groups. The remaining three categories showed very small differences between the two groups (table 5), with summarizing and applying fix-up strategies being the biggest. Expressed in mean scores on the reading comprehension test, the difference between these two groups was very small $\left(M_{I}=16,64 ; M_{C}=15,75\right)$, in favor of the International group, whereas the difference in the total score on the MSI was slightly in favor of the Croatian group, but also minor $\left(M_{I}=9,13 ; M_{C}=8,90\right)$.

\section{Table 5}

Strategy categories mean values - differences between the Croatian and International group

\begin{tabular}{lcccccc}
\hline Group & $\begin{array}{c}\text { Predicting } \\
\text { and } \\
\text { verifying } \\
\text { (7) }\end{array}$ & $\begin{array}{c}\text { Previewing } \\
\text { (2) }\end{array}$ & $\begin{array}{c}\text { Purpose } \\
\text { setting } \\
\text { (3) }\end{array}$ & $\begin{array}{c}\text { Self- } \\
\text { questioning } \\
\text { (3) }\end{array}$ & $\begin{array}{c}\text { DBN } \\
\text { (6) }\end{array}$ & $\begin{array}{c}\text { S \& A } \\
\text { fix- } \\
\text { up } \\
\mathbf{( 4 )}\end{array}$ \\
\hline Cro. (Mc) & 2,00 & 1,13 & 0,63 & 1,00 & 2,38 & 2,00 \\
\hline
\end{tabular}




\begin{tabular}{lcccccc}
\hline Group & $\begin{array}{c}\text { Predicting } \\
\text { and } \\
\text { verifying } \\
\text { (7) }\end{array}$ & $\begin{array}{c}\text { Previewing } \\
\mathbf{( 2 )}\end{array}$ & $\begin{array}{c}\text { Purpose } \\
\text { setting } \\
\mathbf{( 3 )}\end{array}$ & $\begin{array}{c}\text { Self- } \\
\text { questioning } \\
\text { (3) }\end{array}$ & $\begin{array}{c}\text { DBN } \\
\mathbf{( 6 )}\end{array}$ & $\begin{array}{c}\text { S \& A } \\
\text { fix- } \\
\text { up } \\
\mathbf{( 4 )}\end{array}$ \\
\hline Int. $\left(\mathrm{M}_{\mathrm{I}}\right)$ & 1,82 & 1,36 & 0,64 & 1,00 & 2,45 & 1,64 \\
\hline Difference & 0,18 & 0,23 & 0,01 & 0 & 0,07 & 0,36 \\
\hline
\end{tabular}

These findings indicate a similar amount of awareness of strategic behavior before, during, and after reading narrative texts in both groups. Firstly, that could be attributed to the fact that all students were of equal age. As an important factor for attaining higher levels of metacomprehension awareness, age has been recognized on multiple occasions (e.g., Kolić-Vehovec and Bajšanski, 2006; Paris and Winograd, 1990). Secondly, all students underwent the same reading training and routines during the previous school year regardless of their mother tongues, but with certain differentiation of content according to their language levels.

As some of the previous research included the differences pertaining to gender, this study was a good opportunity to look into that matter since the number of girls in this study was almost equal to the number of boys. In terms of reading comprehension, the boys slightly outperformed the girls $\left(M_{M}=16,7 ; M_{F}=15,78\right)$, which is contradictory to some of the previous findings (e.g., Klecker, 2006; Kolić-Vehovec and Bajšanski, 2006; Lynn and Mikk, 2009), but such a small difference could imply inconclusiveness, as suggested by Nietfeld, Shores, and Hoffman (2014). With reference to metacomprehension awareness, the comparison of the mean values of boys' and girls' scores revealed that drawing from background knowledge is the boys' highest score and the girls' second-best (Table 6).

\section{Table 6}

Strategy categories mean values - differences between boys and girls

\begin{tabular}{lcccccc}
\hline Gender & $\begin{array}{c}\text { Predicting } \\
\text { and } \\
\text { verifying } \\
(\mathbf{7})\end{array}$ & $\begin{array}{c}\text { Previewing } \\
(\mathbf{2})\end{array}$ & $\begin{array}{c}\text { Purpose } \\
\text { setting } \\
\mathbf{( 3 )}\end{array}$ & $\begin{array}{c}\text { Self- } \\
\text { questio } \\
\text { ning } \\
\mathbf{( 3 )}\end{array}$ & $\begin{array}{c}\text { DBN } \\
\mathbf{( 6 )}\end{array}$ & $\begin{array}{c}\text { S \& A } \\
\text { fix-up } \\
\mathbf{( 4 )}\end{array}$ \\
\hline Boys $\left(\mathrm{M}_{\mathrm{B}}\right)$ & 2,60 & 1,40 & 0,80 & 1,10 & 3,00 & 1,50 \\
\hline Girls $\left(\mathrm{M}_{\mathrm{G}}\right)$ & 1,11 & 1,11 & 0,44 & 0,89 & 1,78 & 2,11 \\
\hline
\end{tabular}


Silvija HANŽIĆ DEDA

\begin{tabular}{ccccccc}
\hline Gender & $\begin{array}{c}\text { Predicting } \\
\text { and } \\
\text { verifying } \\
\text { (7) }\end{array}$ & $\begin{array}{c}\text { Previewing } \\
\mathbf{( 2 )}\end{array}$ & $\begin{array}{c}\text { Purpose } \\
\text { setting } \\
\mathbf{( 3 )}\end{array}$ & $\begin{array}{c}\text { Self- } \\
\text { questio } \\
\text { ning } \\
\mathbf{( 3 )}\end{array}$ & $\begin{array}{c}\text { DBN } \\
\mathbf{( 6 )}\end{array}$ & $\begin{array}{c}\text { S \& A } \\
\text { fix-up } \\
\mathbf{( 4 )}\end{array}$ \\
\hline Difference & 1,49 & 0,29 & 0,36 & 0,21 & 1,22 & 0,61 \\
\hline
\end{tabular}

Conversely, summarizing and applying fix-up strategies is the girls' top-scored category, and the boys' second-best. In five out of six categories, the difference indicates a higher level of metacomprehension awareness for the group of boys. Only the difference in summarizing and applying fix-up strategies is in favor of the girls. The largest difference between genders can be found in predicting and verifying, and drawing from background knowledge. The lowest level of demonstrated awareness for both groups is present in the category of purpose-setting strategies. Self-questioning and previewing are next in line. Such outcomes suggest that the students are more aware of the strategies which appear lower in the order of thinking skills and are thus more accessible at their age. Predicting and verifying and drawing from background knowledge strategies generated the biggest difference between boys and girls. The remaining four categories revealed relatively small differences.

When comparing the results between International and Croatian boys (Table 7), the metacomprehension awareness score was similar within both subgroups of participants $\left(M_{C M}=10,00 ; M_{I M}=10,67\right)$. On the other hand, when comparing International and Croatian girls, the mean score was in favor of the Croatian girls $\left(M_{C F}=8,25 ; M_{I F}=6,80\right)$, and thus it is possible to determine that the girls whose mother tongue is Croatian demonstrated a somewhat higher level of metacomprehension awareness, which is still lower than in both groups of boys.

\section{Table 7}

Strategy categories mean values - differences between boys and girls

\begin{tabular}{ccccccc}
\hline Group & Gender & $\boldsymbol{n}$ & $\boldsymbol{M}(\boldsymbol{M S I})$ & $\boldsymbol{S D}(\boldsymbol{\sigma})$ & $\boldsymbol{M}(\boldsymbol{R C T})$ & $\boldsymbol{S D}(\boldsymbol{\sigma})$ \\
\hline \multirow{2}{*}{ Croatian } & M & 4 & 10,00 & 3,53 & 15,50 & 3,11 \\
\cline { 2 - 7 } & $\mathrm{F}$ & 4 & $\mathbf{8 , 2 5}$ & 1,9 & 16,00 & 2,58 \\
\hline \multirow{2}{*}{ International } & $\mathrm{M}$ & 6 & 10,67 & 3,9 & 17,50 & 3,11 \\
\cline { 2 - 7 } & $\mathrm{F}$ & 5 & $\mathbf{6 , 8 0}$ & 1,83 & 16,00 & 1,83 \\
\hline
\end{tabular}


A more thorough insight reveals no major differences in reading comprehension scores among the four subgroups, which is a cautious answer to the third research question. However, relatively close reading comprehension scores were achieved via differentiated strategic reading paths: both Croatian and International boys exhibited higher metacomprehension awareness, whereas both groups of girls exhibited a lower level of metacomprehension awareness, especially the girls from the International group. Further examinations are necessary to track possible changes in these occurrences over the following years, since earlier studies suggested that in secondary school boys tend to use fewer reading strategies than girls (e.g., Kolić-Vehovec and Bajšanski, 2006; Medo, 2000). It could be argued that the boys included in this study, regardless of their mother tongues, developed a more elaborate strategic behavior while reading narrative texts in order to be able to follow the reading requirements. As a result, their metacomprehension awareness index increased. On the other hand, previous findings suggesting that girls outperform boys on reading comprehension tests (e.g., Klecker, 2006; Lynn and Mikk, 2009) might mean that girls required fewer reading strategies to achieve a comparable level of reading comprehension to boys. Such occurrence seems to be more pronounced in the International group of girls participating in this study.

\section{Conclusion}

Metacomprehension awareness of plurilingual 10-year-olds reading in English was relatively low, but all participants demonstrated some level of awareness of their own strategic behavior before, during, and after reading a narrative text. The most accessible strategies recorded in this study belong to the categories of previewing, summarizing and applying fix-up strategies, and drawing from background knowledge. At this point, higher-order thinking was less accessible, which was anticipated due to the participants' age. To some extent, such results might be attributed to the nature of training in strategic behavior integrated into everyday classroom instructions. No substantial differences were found between the participants whose mother tongue was Croatian, and the ones whose mother tongue was other than Croatian. 
However, boys outperformed girls on both tests, wherein the lowest level of metacomprehension awareness was recorded in girls whose mother tongue was other than Croatian. In this case, the boys' increased strategic efforts while reading narrative texts enhanced their metacomprehension index, while girls achieved similar scores on the reading comprehension test, but with lower MSI. In this instance, the nature of participants' metacomprehension awareness could not be adequately explained using the variables such as attitudes towards reading narrative texts, reading comprehension scores, nor reading-language preferences.

A tentative conclusion emerging from this study highlights age as a more critical factor in the development of metacomprehension awareness than a diverse language background of a 10-year old individual reading in English. This qualitative-quantitative study of plurilingual fourth-graders adds to the body of research inquiring about similar phenomena. In small countries (such as Croatia), international classes are scarce, and research subjects oftentimes constitute the entire population receiving education according to a specific curriculum. The main characteristics of such research subjects are linguistic and educational diversity, which can generate challenges in data preparation for statistical analyses. Hopefully, more and more meta-analyses of similar cases recorded in different locations will emerge and fill the existing gap in this underresearched area.

\section{Limitations}

Although this is a small-scale study, it contributes to a relatively small body of research focusing on plurilingual primary school students who have only become established readers in their languages of education. What is more, varying participants' language levels, social, and educational backgrounds rendered them a heterogeneous group with a set of variables that are nearly impossible to control for while researching language-related behaviors. However, such educational groups exist in numerous international schools globally, so research in this area is required to create suitable educational policies and teaching practices based on scientific findings. 


\section{References}

Ackerman, J., Nocera, C., \& Bargh, J. (2010). Incidental haptic sensations influence social judgments and decisions. Science, 328, 1712-1715. https://doi.org/10.1126/science.1189993

Baker, L., \& Brown, A. L. (1984). Metacognitive skills and reading. In P. D. Pearson, R. Barr, M. L. Kamil, \& P. Mosenthal (Eds.), Handbook of reading research (pp. 353-394). Longman.

Birketveit, A., Rimmereide, H. E., Bader, M., \& Fisher, L. (2018). Extensive reading in primary school EFL. Acta Didactica Norge, 12(2), 1-23. https://doi.org/10.5617/adno.5643

Brown, A. L. (1985). Metacognition: The development of selective attention strategies for learning from texts. In H. Singer, \& R. B. Ruddell (Eds.), Theoretical models and processes of reading ( $3^{\text {rd }}$ ed., pp. 501-526). International Reading Association.

Baumann, J. F., Seifert-Kessel, N., \& Jones, L. A. (1992). Effects of think-aloud instruction on elementary students' comprehension monitoring abilities. Journal of Reading Behavior, 24(2), 143-172. https://doi.org/10.1080/10862969209547770

Cleary, A. M. (2017). Tip-of-the-tongue states. In J. H. Byrne (Ed.), Learning and memory: A comprehensive reference (Second edition) (pp. 433449). Elsevier Ltd. https://doi.org/10.1016/B978-0-12-8093245.21059-6

Coste, D., Moore, D., \& Zarate, G. (2009). Plurilingual and pluricultural competence. Council of Europe - Language Policy Unit. https://biblioteka.womczest.edu.pl/new/wpcontent/uploads/2013/09/plurilingual_and_pluricultural_competence. pdf

Cox, B. E. (1994). Young children's regulatory talk: Evidence of emergent metacognitive control over literary products and processes. In R. Ruddell, M. Ruddell, \& H. Singer (Eds.) Theoretical models and processes of reading ( $4^{\text {th }}$ ed., pp. 733-756). International Reading Association.

Davey, B., \& Porter, S. (1982). Comprehension-rating: A procedure to assist 
poor comprehenders. Journal of Reading, 26(3), 197-202. http://www.jstor.org/stable/40031705

De Bruin, A. B. H., Thiede, K., Camp, G., Redford, J. (2011). Generating keywords improves metacomprehension and self-regulation in elementary and middle school children. Journal of Experimental Child Psychology, 109(3), 294-310. https://doi.org/10.1016/j.jecp.2011.02.005

Destan, N., Roebers, C. M. (2015). What are the metacognitive costs of young children's overconfidence? Metacognition and Learning, 10, 347-374. https://doi.org/10.1007/s11409-014-9133-z

Ehri, L. C. (2005). Learning to read words: Theory, findings, and issues. Scientific Studies of Reading, 9(2), 167-188. https://doi.org/10.1207/s1532799xssr0902_4

Flavell, J. (1979). Metacognition and cognitive monitoring: A new era of cognitive-developmental inquiry. American Psychologist, 34(10), 906911. https://doi.org/10.1037/0003-066X.34.10.906

Klecker, B. M. (2006). The gender gap in NAEP fourth-, eighth-, and twelfthgrade reading scores across years. Reading Improvement, 43(1), 5056.

Kletzien, S. B. (1992). Proficient and less proficient comprehenders' strategy use for different top-level structures. Journal of Reading Behavior, 24(2), 191-215. https://doi.org/10.1080/10862969209547772

Kolić-Vehovec, S., \& Bajšanski, I. (2006). Metacognitive strategies and reading comprehension in elementary school students. European Journal of Psychology of Education, 21, 439-451. http://dx.doi.org/10.1007/BF03173513

Kolić-Vehovec, S., \& Bajšanski, I. (2007). Comprehension monitoring and reading comprehension in bilingual students. Journal of Research in Reading, 30, 198-211. https://doi.org/10.1111/j.14679817.2006.00319.x

Lietz, P. (2006). A meta-analysis of gender differences in reading achievement at the secondary school level. Studies in Educational Evaluation, 32, 317-344. https://doi.org/10.1016/j.stueduc.2006.10.002

Lipp, E. (2017). Building self-efficacy, strategy use, and motivation to support 
extensive reading in multilingual university students. The CATESOL Journal, 29(2), 21-39.

Luke, A. (2000). Critical literacy in Australia: A matter of context and standpoint. Journal of Adolescent and Adult Literacy, 42, 448-461. http://www.jstor.org/stable/40017081

Lujić, R., \& Hanžić Deda, S. (2018). Plurilingual primary school students and their language use. Sustainable Multilingualism, 12, 114-129. https://doi.org/10.2478/sm-2018-0005

Lynn, R., \& Mikk, J. (2009). Sex differences in reading achievement. Trames Journal of the Humanities and Social Sciences, 13(1), 3-13. http://dx.doi.org/10.3176/tr.2009.1.01

Martin, A. (1994). Case study of a good reader and a poor reader at the primary level: The construction of meaning. DAI-A, 33(5), 1386.

Medo, M. A. (2000). The status of high school students' learning strategies: What students do when they read to acquire knowledge (Publication No. 9966252). [Doctoral dissertation, University of Minnesota]. ProQuest Dissertations Publishing.

Meniado, J. (2016). Metacognitive reading strategies, motivation, and reading comprehension performance of Saudi EFL students. English Language Teaching, 9(3), 117-129. http://dx.doi.org/10.5539/elt.v9n3p117

Miller, P. H. (2010). Piaget's theory: Past, present, and future. In U. Goswami (Ed.), The Wiley-Blackwell Handbook of Childhood Cognitive Development, Second edition (pp. 649-672). Wiley-Blackwell.

Mirandola C., Ciriello A., Gigli M., and Cornoldi C. (2018). Metacognitive monitoring of text comprehension: An investigation on postdictive judgments in typically developing children and children with reading comprehension difficulties. Frontiers in Psychology, 9, 2253. https://doi.org/10.3389/fpsyg.2018.02253

Mokhtari, K., \& Reichard, C. A. (2002). Assessing students' metacognitive awareness of reading strategies. Journal of Educational Psychology, 94(2), 249-259. https://doi.org/10.1037/0022-0663.94.2.249

Nietfeld, J., Shores, L., \& Hoffman, K. (2014). Self-regulation and gender within a game-based learning environment. Journal of Educational Psychology, 106(4), 961-973. https://doi.org/10.1037/a0037116 
Paris, S. G., \& Winograd, P. (1990). How metacognition can promote academic learning and instruction. In B. F. Jones, \& L. Idol (Eds.), Dimensions of thinking and cognitive instruction (pp. 15-51). Lawrence Erlbaum Associates.

Paris, S. G., \& Flukes, J. (2005). Assessing children's metacognition: About strategic reading. In S. E. Israel et al. (Eds.), Metacognition in literacy learning (pp. 121-139). Lawrence Erlbaum Associates.

Pazzaglia, F., De Beni, R., \& Caccio, L. (1999). The role of working memory and metacognition in reading comprehension difficulties. In T. E. Scruggs, \& M. A. Mastropieri (Eds.), Advances in learning and behavioral disabilities, v. 13 (pp. 115-134). JAI.

Pintrich, P. R., \& Zusho, A. (2002). The development of academic selfregulation: The role of cognitive and motivational factors. In A. Wigfield, \& J. S. Eccles (Eds.), Development of achievement motivation (pp. 249-284). Academic Press. https://doi.org/10.1016/B978-012750053-9/50012-7

Jiménez, V., Puente, A., Alvarado, J. M., Arrebillaga, L. (2009). Measuring metacognitive strategies using the reading awareness scale ESCOLA. Electronic Journal of Research in Educational Psychology, 7(2), 779804. https://doi.org/10.25115/ejrep.v7i18.1326

Rowe, D. (1994). Preschoolers as authors: Literacy learning in the social world of the classroom. Hampton Press.

Ruan, J. (2004). Bilingual Chinese/English first graders developing metacognition about writing. Journal of Literacy, 38(2), 106-112. https://doi.org/10.1111/j.0034-0472.2004.03802007.x

Rutter, M., Caspi, A., Fergusson, D. M., Horwood, L. J., Goodman, R., Maughan, B., Moffitt, T. E., Meltzer, H., \& Carroll, J. (2004). Sex differences in developmental reading disability: New findings from 4 epidemiological studies. Journal of the American Medical Association, 291, 2007-2012. http://dx.doi.org/10.1001/jama.291.16.2007

Schmitt, M. C. (1990). A questionnaire to measure children's awareness of strategic reading processes. The Reading Teacher, 43, 454-461.

Schmitt, M. C. (2003). Metacognitive strategy knowledge: Comparison of former Reading Recovery children and their current classmates. 
Literacy Teaching and Learning, 7 (1-2), 57-76.

Schraw, G., \& Sperling Dennison, R. (1994). Assessing metacognitive awareness. Contemporary Educational Psychology, 19(4), 460-475. https://doi.org/10.1006/ceps.1994.1033

Stille, S. and Cummins, J. (2013). Foundation for learning: Engaging plurilingual students' linguistic repertoires in the elementary classroom. TESOL $Q$ 47(3), 630-638. https://doi.org/10.1002/tesq.116

Sun, B., Loh, C. E., \& Curdt-Christiansen, X. L. (2020). Leisure reading in multilingual Singapore: Reading enjoyment, habits and preferences of Singaporean children. Journal of Multilingual Theories and Practices, 1(2), 313-339. https://doi.org/10.1558/jmtp.17610

Šamo, R., \& Mikulec, A. (2018). EFL reading metacomprehension from the developmental perspective: A longitudinal case study. Journal of Language and Education, 4(1), 105-116. https://doi.org/0.17323/2411-7390-2018-4-1-105-116

Temelman-Yogev, L., Katzir, T., \& Prior, A. (2020). Monitoring comprehension in a foreign language: Trait or skill? Metacognition Learning 15, 343365 (2020). https://doi.org/10.1007/s11409-020-09245-5

White, B. (2007). Are girls better readers than boys? Which boys? Which girls? Canadian Journal of Education, 30(2), 554-581. https://doi.org/10.2307/20466650

Yüksel, I., \& Yüksel I. (2011). Metacognitive awareness of academic reading strategies. Procedia - Social and Behavioral Sciences, 31, 894-898. https://doi.org/10.1016/j.sbspro.2011.12.164

Zápotočná, O., Urban, K., and Urban, M. (2020). Comprehension and metacomprehension in preschoolers from low- and middlesocioeconomic status families. Československá psychologie, 64(6), 625-638. https://ceskoslovenskapsychologie.cz/index.php/csps/ article/view/4 


\section{Appendix}

Figure 4

Metacomprehension Strategy Index (MSI) and reading comprehension test $(R C T)$ - a parallel view

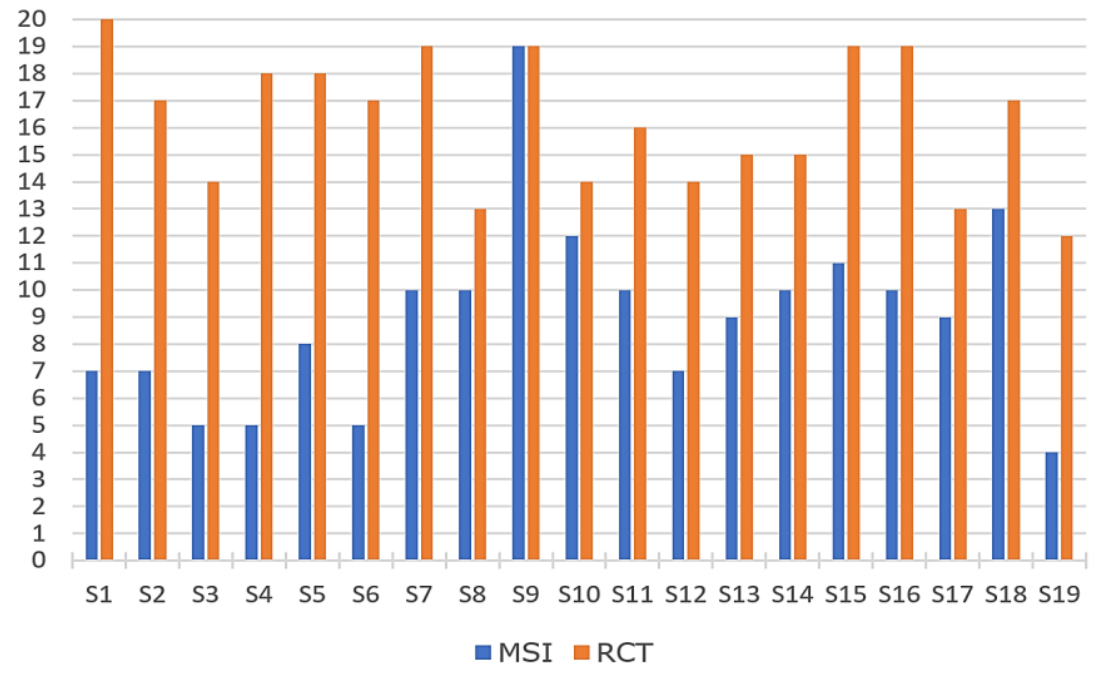




\section{Silvija Hanžić Deda}

Zagrebo universitetas, Kroatija

silvija.hanzic@gmail.com

\section{DAUGIAKALBIU PRADINÉS MOKYKLOS MOKINIY METASUVOKIMO PAŽINIMAS}

Santrauka. Šiame kokybiniame ir kiekybiniame tyrime analizuojamas tarptautinès pradinès mokyklos mokiniu metasuvokimo pažinimo lygis prieš naratyviniu tekstu skaityma, skaitant tekstus ir juos perskaičius. Pirmoje tyrimo dalyje pateikiama trumpa teorinio konteksto ir ankstesnic tyrimu, susijusiu su metasuvokimu ir metakognityvinèmis strategijomis, teksto suvokimu ir daugiakalbyste, apžvalga formaliojo švietimo kontekste. Antroje dalyje aprašyti dalyviai ir skirtinga ju asmeninè patirtis, susijusi su kalba ir švietimu. Didžioji dalis informacijos surinkta iš dvieju tyrimu ir trumpo klausimyno. Buvo rengiami pusiau struktūrizuoti pokalbiai, siekiant išsiaiškinti dalyviu požiūri i naratyviniu tekstu skaityma ir kalbas, kurias dalyviai pirmiausia rinkosi šiems tekstams skaityti. Paaiškèjo, jog dešimtmẽčiai daugiakalbiai mokiniai, skaitydami naratyvinius tekstus anglu kalba, pademonstravo tam tikra metasuvokimo pažinima. Dvi konkrečios grupès, nustatytos pagal ju gimtaja kalba, iš esmès nesiskyrè, bet atsiskleidè tam tikri skirtumai tarp berniuku ir mergaičiu. Tyrimu nustatyti skaitymo kalbos ir kalbos pasirinkimai skaitant naratyvinius tekstus atlieka svarbu vaidmeni siekiant veiksmingo teksto suvokimo, o amžius yra svarbesnis veiksnys tobulinant dešimtmẽčiu daugiakalbiu vaiku metasuvokimo pažinima.

Pagrindinès sąvokos: tarptautinè pradinè mokykla; metasuvokimo strategijos rodiklis; naratyviniai tekstai; daugiakalbiai skaitytojai; teksto suvokimas. 